\title{
High Dividend Shares Investment Decision in Indonesia Stock Exchange: Bottom-Up Approach
}

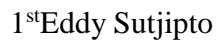 \\ Department of Accounting \\ Universitas Semarang \\ Semarang, Indonesia \\ eddy.sutjipto@usm.ac.id
}

\author{
$2^{\text {nd }}$ Wawan Setiawan \\ Department of Management \\ Universitas Semarang \\ Semarang, Indonesia \\ uaone@usm.ac.id
}

\author{
$3^{\text {rd }}$ Dyah N.A. Janie \\ Department of Accounting \\ Universitas Semarang \\ Semarang, Indonesia \\ dyahjanie@usm.ac.id
}

\begin{abstract}
Investing in the capital market is high risk and return. Hence, investors need to use the right strategy by using the bottom line, primarily to determine the intrinsic value of shares. The problem is currently around $85-90 \%$ of capital market players in Indonesia experiencing failure because of using the strategy as a trader and not as an investor. Besides that, most research limited the intrinsic value to case studies. The sample of this study was 64 companies $(11 \%$ of the total listed companies will be sampling), dividing the dividends in 2014 . 2018 that never suffer a loss. Meanwhile, the method used in determining the intrinsic value of shares is the $P / E$ method. The results show that 46 companies have undervalued shares, but only five companies are worth buying because the Margin of Safety (MOS) is above $30 \%$ and ROE, EPS growth for five years are still positive. Meanwhile, 18 other companies are overvalued, or the intrinsic value is smaller than the stock price. Furthermore, both undervalued and overvalued in returns until the end of December 2019, it turns out that undervalued shares with MOS> 30\% provide higher returns than undervalued $<30 \%$ and those that are overvalued. Thus the calculation of intrinsic value by the $P / E$ ratio method can be said to be accurate, and previous studies have never evaluated this before.
\end{abstract}

Keywords - dividend, intrinsic value, MOS and P / E

\section{INTRODUCTION}

Investing means reducing current consumption to get better results in the future. Investment instruments are varied, which can be in the form of Saving, Deposit, Gold, Mutual Fund, and Stock [1]. Stock investment is one investment that is considered to be able to provide the greatest return and is finally known as high-risk, high return. We cannot assume that opinion for investors because they generally study the fundamentals of the company deeply.

Meanwhile, to choose the stock that can minimize the risk of loss due to the falling of prices and obtain optimal returns, it is necessary to use the Intrinsic Value approach. The intrinsic value of the stock is the fair value of a company determined from the company's fundamentals regardless of the stock market price [2]. The calculation of intrinsic value with the P/E ratio approach uses relatively similar data and can help investors in making investment decision [3], [4]. Then investors can compare with current market prices with the intrinsic value so we can understand whether the stocks are undervalued or overvalued. However, it is necessary to pay attention to the Margin of Safety (MoS)to make a purchase, namely for bluechip stock, if there is a discount of at least $30 \%$ of the intrinsic value and discounts 50\% for stocks that are not blue-chip [5].

Stock selection using this method does not guarantee investors will not lose, so it is necessary to conduct further analysis of the company's leverage and the prospects of its
Business sector. Companies that have large debts will be able to risk default or profit and even lose because investors sell many stocks, so the stock price falls. Thus it can be concluded that leverage negatively affect stock return [6], [7]

\section{THEORETICAL REVIEW}

\section{A. Investment}

Investment always has two sides, namely, return and risk. In investing, the law that the higher the return offered, the higher the risk (high-risk, high return) that must be borne by investors is applied [8]. Investors can lose, even more than that, they can lose all of their capital. It might explain why not all investors allocate funds to all investment instruments that offer high returns, so investors need to specify their investment goals clearly [9].

The definition of investment is very diverse or quite a lot and depends on the purpose. Investment is a commitment to invest several funds at present to obtain profits in the future [10]. In contrast, other researchers explain that investment is a capital investment for one or more assets that are owned and are usually of a long-term in the hope of earning profits in the future in the form of dividend or capital gain [11]. In other words, investment is a commitment to sacrifice current consumption to increase consumption in the future.

Investing in capital markets for the long term generally analyzes deeply about the fundamental of the company so that we know the intrinsic value of the shares. The analysis is the bottom-up analysis that includes the understanding of the business and industry, understanding the company's strategy, being able to predict its performance, and valuing the company's shares [4], [12]. Performing stock valuation will produce information about the intrinsic value, which will then be compared with the stock market price to determine the selling or buying position of a company's shares [10]. The fair price or intrinsic value of an asset is the cost of goods sold of the ownership of an asset after comparing the required rate of return with the expected rate of return that the asset can provide in the future [13].

\section{B. Intrinsic value}

By using the $\mathrm{P} / \mathrm{E}$ ratio approach, the company's performance mostly determines the intrinsic value of shares. The better the company's performance, the higher the company's stock price because many investors are interested in buying the shares. The company's financial performance used in determining the intrinsic value of the P / E method includes EPS, dividends, PER, and ROE. 


\section{Earnings Per Share (EPS)}

Earnings per Share (EPS) is an essential element for investors. EPS is a comparison between the amount of profit (net income) and the number of circulating shares [10]. If a company's EPS increases, then shareholders tend to get a share of profits in the form of a hefty dividend. It means that the company makes a profit, and if it suffers losses, the EPS does not increase. For investors, EPS is valuable information because we can use it to predict future earnings.

EPS fluctuation is an essential element in the process of selecting the superior stock [14]. A good stock is a stock that has increased at least $25 \%$ every semester or every year. In this case, the investor must consider the increase in sales during this period, because it is possible that the sale only increases by $5 \%$, but the net profit increases by $25 \%$ so that the EPS increases very high. It is so apparent that an increase in sales will increase EPS or from the results of the company's main operation, but the results of Non-Operational activities such as asset sales. In practice, we must conduct EPS analysis carefully because it can be misleading [15]. We calculate EPS based on the net profit gained during one accounting period divided by the number of circulating shares. While the number of circulating shares may change due to the presence of the right issue, split stock, ESOP (Employee Stock Ownership Plan), Warrant, Convertible Bond, and corporate action. EPS information in print media is often not informative, and there may be a specific purpose, so the numbers that appear are seen big because they do not pay attention to the additional circulating shares.

\section{Dividend}

The dividend is the distribution of profit provided by the company issuing the shares of the profit obtained by the company [8]. Dividends are usually highly waited by investors. They use them as a signal that the company has a reasonable prospect or not. Usually, the companies that can provide dividends with large yield, especially those derived from the results of the company's main business activities, investors will respond positively so that stock return increases, and this reaction is in line with the theory of signyal[16], [17]. It is one of the goals expected by the value investors and some speculative investors, as a result of investing in shares. With the distribution of dividends, the company will be a deduction of the company's funding sources.

Companies generally cannot be routinely giving dividends every year, and the amount is also different. In contrast, the factors that can influence companies in providing dividends are (a) the availability of sufficient liquidity, (b) the need to pay off debt, and (c) the need for funds to expand. Thus the amount of the dividend is related to the dividend policy carried out by the company [18]. This possibility refers to the opinion of Miller and Modigliani (M-M), which states that dividend policy has no influence or is irrelevant to the stock market price [17]. We consider the distribution of dividends irrelevant because the amount of the Dividend Payout Ratio (DPR) does not determine the price of a company's shares. However, net income before tax (EBIT) does.

\section{E. Price Earning Ratio (PER)}

Price Earning Ratio (PER) explains the comparison of the market price of each sheet of shares to EPS (earnings per sheet of shares). PER illustrates the market's appreciation of the company's ability to generate profit [19]. This ratio shows how.
Much the investors value the price of a share against the multiple of earnings. "A high PER indicates that investors are willing to pay at a premium share price or a price above the market price. The most important thing is the increase in earnings per share annually.

Until now, many investors around the world consider that low PER means undervalue stock price so that it is feasible to buy. Moreover, high PER stock means it is overvalued, so they need to sell. However, the top leading stocks from 1952 until now show that PER is not relevant in changing stock prices [14]. We can see that on the IDX that there are some shares whose PER remains high, and the prices are high too, for example, Uniliver and Gudang Garam shares. Therefore, he suggests that investors should examine the low PER caused by the changes in EPS slump or not [14].

\section{F. Return on Equity (ROE)}

Return on Equity (ROE) is a ratio used to measure the ability of own capital to generate profits for all shareholders, for ordinary shares and preferred shares. The higher the value of ROE, of course, the more investors will invest their capital in the company because it indicates that the company has excellent performance. Consequently, share prices will also go up. This ratio is a measurement of profitability based on the perspective of shareholders. The greater ROE reflects the company's ability to generate high returns for shareholders or the more efficient in using the company's capital. The leading stocks have a minimum ratio of $17 \%$. We can use the ratio to classify companies that are well managed and not [14].

\section{G. Investment decision}

Making an investment decision using the basis of the intrinsic value of the stock should determine whether the stock is undervalued or overvalued [20], [21]. The stock is said to be under-valued if the intrinsic value is higher than the price of the stock and vice versa, it is said to be overvalued if the intrinsic value is smaller than the market price. Nevertheless, investors should choose shares that are under-valued if the Margin of Safety (MOS) is at least $30 \%$ or when the stock price is $30 \%$ below the intrinsic value [22].

\section{RESEARCH METHOD}

This study uses data from companies that routinely distribute cash dividends during the 2014-2018 period and have never suffered a loss. The number of samples taken was 64 companies (10.3\%) from a total of 622 companies listed on the Indonesia Stock Exchange (IDX). In detail, the samples taken are as follows:

TABLE I. LIST OF SAMPLES

\begin{tabular}{|c|l|r|r|r|}
\hline & \multicolumn{1}{|c|}{ Sector } & Total & Sample & Percent \\
\hline 1. & $\begin{array}{l}\text { Miscellaneous } \\
\text { Industry }\end{array}$ & 46 & 3 & $7 \%$ \\
\hline 2. & $\begin{array}{l}\text { Consumer } \\
\text { goods Indus }\end{array}$ & 50 & 11 & $22 \%$ \\
\hline 3. & $\begin{array}{l}\text { Basic } \\
\text { Industry } \\
\text { and Ch }\end{array}$ & 71 & 6 & $8 \%$ \\
\hline 4. & $\begin{array}{l}\text { Infrastructure, } \\
\text { Utilities }\end{array}$ & 71 & 2 & $3 \%$ \\
\hline 5. & Finance & 91 & 16 & $18 \%$ \\
\hline 6. & $\begin{array}{l}\text { Trade, Service } \\
\& \text { In }\end{array}$ & 153 & 11 & $7 \%$ \\
\hline 7. & Mining & 47 & 7 & $15 \%$ \\
\hline 8. & Agriculture & 20 & 2 & $10 \%$ \\
\hline 9. & $\begin{array}{l}\text { Property, Real } \\
\text { Estate }\end{array}$ & 73 & 6 & $8 \%$ \\
\hline TOTAL & 622 & 64 & $10.3 \%$ & \\
\hline
\end{tabular}


While the data taken from IDX are Return on Equity (ROE), Dividend, Earning Per Share (EPS), and Dividend Payout Ratio (DPR).

The following steps are used in determining the intrinsic value of a stock:

1. Calculate Retention Ratio $(\mathrm{RR})=1$ - Dividend Payout Ratio (the last year)

2. Calculate Expected Growth Ratio $(\mathrm{g})=$ Average ROE for 5 years $x$ Retention Ratio (RR)

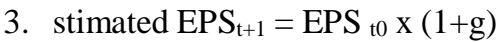

4. Estimated Cash Dividend $\left(\right.$ Dividend $\left._{t+1}\right)=\mathrm{EPS}_{\mathrm{t}+1} \times \mathrm{g}$

5. Determining the amount of return $(\mathrm{k})=$ Dividend $_{\mathrm{t} 0}+\mathrm{g}$

6. Estimated Price Earning Ratio $(\mathrm{PER})=\left(\right.$ Dividend $_{\mathrm{t} 0} / \mathrm{EPS}$ $\mathrm{t} 0) /(\mathrm{k}-\mathrm{g})$

7. Calculate Intrinsic Value $=\mathrm{EPS}_{\mathrm{t}+1} \times \mathrm{PER}$

8. Determining Undervalue or Overvalue

a. Intrinsic Value $>$ Stock Price $=$ Undervalue

b. Intrinsic Value $=$ Stock Price $=$ Fair Value

c. Intrinsic Value $<$ Stock Price $=$ Overvalue

9. Calculate Margin of Safety $(\mathrm{MOS})=($ Intrinsic Value Price) / Intrinsic Value.

10. Share purchasing recommendations with the minimum risk of loss is:

a. According to Graham [5] it is better choosing stock with MOS minimally $30 \%$.

b. EPS and ROE growth minimally $15 \%$, and Debt to Equity is low [14].

\section{RESULTS AND DISCUSSION}

\section{A. Sector Performance}

In general, the rising or falling of stock prices can be influenced by the company's fundamental factors in the form of dividends, DPR, EPS, and ROE. Based on the data of the average growth of Price, PER, dividend, DPR, EPS, and ROE for the 2014-2018 period, it is known as follows:

TABLE II. The Average Growth of Price, PER, Dividend, DPR, EPS AND ROE PERIOD 2014 - 2018

\begin{tabular}{|l|r|r|r|r|r|r|}
\hline \multicolumn{1}{|c|}{ Sector } & Price & PER & Dividend & DPR & EPS & ROE \\
\hline Mining & 10 & 6 & 80 & 227 & 87 & 79 \\
\hline Consumer & 13 & 101 & 7 & 7 & 3 & 25 \\
\hline $\begin{array}{l}\text { Basic } \\
\text { Industry }\end{array}$ & 5 & 88 & 1 & 13 & -5 & 15 \\
\hline Misc-Inds & 3 & 9 & 11 & 14 & 3 & 12 \\
\hline Finance & 18 & 25 & 15 & 16 & 11 & 11 \\
\hline Trade & 0 & -3 & 25 & 20 & 11 & 2 \\
\hline Property & -14 & 208 & 11 & 10 & 6 & -5 \\
\hline Infrastruc & -3 & 6 & 4 & 6 & -2 & -17 \\
\hline Agriculture & -6 & 229 & 21 & 9 & -15 & -17 \\
\hline Average & 3 & 74 & 20 & 36 & 11 & 12 \\
\hline
\end{tabular}

Based on the data above, we can see the relationship between share price growth, PER, dividends, DPR, EPS, and ROE. During the 2014-2018 period, the positive average ROE
Growth in the Mining, Consumer Goods Industry, Basic Industry and Chemicals, Miscellaneous Industry, and Finance sectors followed by an increase in stock prices reflected in the positive growth in average stock prices. Likewise, on the contrary, that the growth of ROE is harmful; there is a tendency for the share price to decline, or the average growth of the share price is negative.

\section{B. Intrinsic Value}

The difference between the intrinsic value of shares and stock prices divided into three types, namely undervalue, fair value, and overvalue.

\section{1) Worth Buying Undervalued Stock}

Investors generally buy shares to be saved in the long term so that they can get dividends and the difference between the selling price and the purchasing price (gain). The decision to buy should have an intrinsic value higher than the market price (undervalue) and with minimum Margin of Safety (MOS) of $30 \%$. The following is the list of stocks that are worth buying by investors.

TABLE III. LIST OF UNDERVALUES SHARES THAT ARE WORTH BUYING

\begin{tabular}{|l|l|l|r|r|r|l|}
\hline No & Code & Sector & PER & $\begin{array}{c}\text { Intrinsic } \\
\text { Value }\end{array}$ & $\begin{array}{c}\text { Price, } \\
\text { Nop, } \\
\mathbf{2 0 1 9}\end{array}$ & MOS \\
\hline 1 & ITMG & Mining & 5.8 & 22,000 & 10,225 & $54 \%$ \\
\hline 2 & INKP & Basic-Ind & 12.8 & 12,450 & 6,800 & $45 \%$ \\
\hline 3 & BSSR & Mining & 6.2 & 2,945 & 1,825 & $38 \%$ \\
\hline 4 & TCID & Consumer & 20.0 & 18,500 & 11,700 & $37 \%$ \\
\hline 5 & TURI & Trade & 11.9 & 1,330 & 925 & $30 \%$ \\
\hline
\end{tabular}

The data in the form of DER, EPS, ROE, and Market Capitalization are as follows.

TABLE IV. LIST OF DER, EPS, ROE AND MARKET CAPITALIZATION

\begin{tabular}{|l|l|l|r|r|r|r|}
\hline No & Code & Sector & DER & \multicolumn{1}{|c|}{$\begin{array}{c}\text { EPS } \\
\text { Growth }\end{array}$} & \multicolumn{1}{c|}{$\begin{array}{c}\text { ROE } \\
\text { Growth }\end{array}$} & $\begin{array}{c}\text { Market } \\
\text { Capt } \\
\text { (Trillion) }\end{array}$ \\
\hline 1. & ITMG & Mining & 0.55 & 190 & 184 & 4.8 \\
\hline 2. & INKP & Basic-Ind & 0.26 & 25 & 12 & 2.4 \\
\hline 3. & BSSR & Mining & 0.7 & 19 & 9 & 5.2 \\
\hline 4. & TCID & Consumer & 0.47 & 18 & 20 & 11.6 \\
\hline 5. & TURI & Trade & 1.02 & 17. & 14 & 78.1 \\
\hline
\end{tabular}

Based on the table, we can see that (a) in the mining sector. Two companies are worth buying, namely ITMG and BSSR because the prices have already been meager or the prices have decreased by $54 \%$ and $38 \%$ of the intrinsic value. The growth of EPS and ROE for five years is very high, namely more than $17 \%$ and with low DER or less than one, so the risk is low. The two shares are quite liquid, with more than one billion circulating shares and market capitalization of more than $\mathrm{Rp} 4$ trillion. By judging from the prospects of the sector, there is still hope that coal prices will increase. If the Chinese and American economies increase or the trade war subsides, and renewable energy substitutes gained in the short term. Thus now is the right time to buy these shares. (b) INKP from the Basic Industry sector is still doing well, seeing that DER is still below one and EPS and ROE growth for five years is still above $10 \%$, and MOS is $45 \%$. The prospect for the industry's performance is still good hopes because the need for paper is still high, and the number of paper producers is still relatively limited. (c) TCID and TURI shares from the Consumer and Trade sector have excellent performance, 
namely DER below one and EPS, and ROE growth is still above $13 \%$, and the sector's prospect is still good.

\section{2) Not Worth Buying Undervalue Shares}

Stocks with the intrinsic value higher than the stock price or undervalue are not to buy because their performance tends to decrease, for example, the growth of EPS and ROE for five years. The following are the undervalue stock data recommended not to buy.

TABLE V. LIST OF UNDERVALUES STOCK

\begin{tabular}{|c|c|c|c|c|c|c|}
\hline Code & Price $^{\mathrm{a}}$ & $\begin{array}{c}\text { Intrinsic } \\
\text { Value }\end{array}$ & MOS & DER & $\triangle E P S$ & $\triangle \mathrm{ROE}$ \\
\hline \multicolumn{7}{|c|}{ Agriculture } \\
\hline AALI & 12.6 & 12.675 & $1 \%$ & 0.5 & $-5 \%$ & $-16 \%$ \\
\hline \multicolumn{7}{|c|}{ Basic Industry } \\
\hline SMBR & 390 & 1.85 & $79 \%$ & 0.6 & $-29 \%$ & $-26 \%$ \\
\hline$\overline{\text { SMGR }}$ & 11.45 & 12.2 & $6 \%$ & 1.5 & $-11 \%$ & $5 \%$ \\
\hline TOTO & 288 & 370 & $22 \%$ & 0.5 & $-25 \%$ & $110 \%$ \\
\hline \multicolumn{7}{|c|}{ Consumer Goods } \\
\hline CINT & 252 & 300 & $16 \%$ & 0.3 & $-20 \%$ & $-12 \%$ \\
\hline HMSP & 1.935 & 3.7 & $48 \%$ & 0.6 & $-15 \%$ & $-8 \%$ \\
\hline ICBP & 11.325 & 11.7 & $3 \%$ & 0.5 & $4 \%$ & $5 \%$ \\
\hline INDF & 7.95 & 7.975 & $0 \%$ & 1,0 & $5 \%$ & $3 \%$ \\
\hline KAEF & 1.735 & 1.85 & $6 \%$ & 1.3 & $-6 \%$ & $276 \%$ \\
\hline KLBF & 1.525 & 1.66 & $8 \%$ & 0.2 & $4 \%$ & $-5 \%$ \\
\hline UNVR & 41.8 & 48.9 & $15 \%$ & 2,0 & $5 \%$ & $-1 \%$ \\
\hline \multicolumn{7}{|c|}{ Finance } \\
\hline AGRO & 140 & 325 & $57 \%$ & 4.6 & $-10 \%$ & $-7 \%$ \\
\hline$\overline{\mathrm{ASRM}}$ & 2 & 2.6 & $23 \%$ & 2.5 & $4 \%$ & $-16 \%$ \\
\hline BBNI & 7.5 & 9.725 & $23 \%$ & 6.1 & $8 \%$ & $-4 \%$ \\
\hline$\overline{\mathrm{BBTN}}$ & 2.13 & 2.8 & $24 \%$ & 10,0 & $23 \%$ & $6 \%$ \\
\hline BDM & & & & & & \\
\hline $\mathrm{N}$ & 3.68 & 8 & $54 \%$ & 3.5 & $6 \%$ & $5 \%$ \\
\hline$\overline{B F I N}$ & 570 & 700 & $19 \%$ & 2.3 & $48 \%$ & $4 \%$ \\
\hline$\overline{\mathrm{BJBR}}$ & 1.57 & 2.18 & $28 \%$ & 8.4 & $11 \%$ & $-6 \%$ \\
\hline BJTM & 650 & 755 & $14 \%$ & 6.4 & $20 \%$ & $-2 \%$ \\
\hline BMRI & 6.975 & 7.975 & $13 \%$ & 5.1 & $2 \%$ & $-3 \%$ \\
\hline \multicolumn{7}{|c|}{ Infrastructure } \\
\hline PGAS & 1.92 & 2.27 & $15 \%$ & 1.1 & $-13 \%$ & $-17 \%$ \\
\hline \multicolumn{7}{|c|}{ Mining } \\
\hline$\overline{\mathrm{ADRO}}$ & 1.23 & 1.285 & $4 \%$ & 0.7 & $38 \%$ & $22 \%$ \\
\hline ELSA & 272 & 375 & $28 \%$ & 0.8 & $-3 \%$ & $-12 \%$ \\
\hline GEMS & 2.55 & 2.9 & $12 \%$ & 1.2 & $280 \%$ & $316 \%$ \\
\hline PTBA & 2.42 & 4.6 & $47 \%$ & 0.5 & $-9 \%$ & $11 \%$ \\
\hline \multicolumn{7}{|c|}{ Miscellaneous Industry } \\
\hline ASII & 6.5 & 8.85 & $27 \%$ & 1,0 & $3 \%$ & $19 \%$ \\
\hline AUTO & 1.195 & 1.5 & $20 \%$ & 0.5 & $7 \%$ & $-6 \%$ \\
\hline \multicolumn{7}{|c|}{ Property } \\
\hline ADHI & 1.075 & 1.72 & $38 \%$ & 4,0 & $0 \%$ & $-4 \%$ \\
\hline$\overline{\mathrm{NRCA}}$ & 370 & 400 & $8 \%$ & 0.9 & $0 \%$ & $-18 \%$ \\
\hline PTPP & 1.35 & 2.02 & $33 \%$ & 2.3 & $8 \%$ & $-10 \%$ \\
\hline TOTL & 406 & 620 & $35 \%$ & 2.1 & $4 \%$ & $-1 \%$ \\
\hline WIKA & 1.735 & 1.81 & $4 \%$ & 2.4 & $10 \%$ & $-3 \%$ \\
\hline \multicolumn{7}{|c|}{ Trade } \\
\hline ACES & 1.58 & 1.66 & $5 \%$ & 0.2 & $10 \%$ & $0 \%$ \\
\hline AKRA & 3.4 & 4.49 & $24 \%$ & 1,0 & $1 \%$ & $4 \%$ \\
\hline$\overline{\mathrm{ASGR}}$ & 920 & 1.46 & $37 \%$ & 0.7 & $-8 \%$ & $-17 \%$ \\
\hline LPPF & 3.53 & 6.3 & $44 \%$ & 1.8 & $6 \%$ & $-5 \%$ \\
\hline PGLI & 250 & 278 & $10 \%$ & 0.4 & $50 \%$ & $55 \%$ \\
\hline SCMA & 1.2 & 2.29 & $48 \%$ & 0.2 & $-1 \%$ & $-10 \%$ \\
\hline TELE & 284 & 1.035 & $73 \%$ & 1.2 & $12 \%$ & $-6 \%$ \\
\hline UNTR & 20.925 & 29.5 & $29 \%$ & 1,0 & $17 \%$ & $14 \%$ \\
\hline
\end{tabular}

Based on the data, there are 22 shares with MOS of more than $20 \%$. However, the financial ratio in the form of EPS and ROE growth tends to be harmful, or experience decline and many DER ratios are more than one, so the shares are not eligible to be purchased even though they can provide dividends to shareholders.

\section{3) Overvalue Stocks}

The intrinsic value calculation results higher than the stock price is said to be overvalued. This category of stock is not worth buying because there is a tendency that the price will decline so that investors can suffer losses. Here is the list of overvalued companies.

TABLE VI. LIST OF OVERVALUE STOCK

\begin{tabular}{|c|c|c|c|c|c|c|}
\hline Code & Price $^{b}$ & $\begin{array}{c}\text { Intrinsic } \\
\text { Value }\end{array}$ & MOS & DER & $\Delta$ EPS & $\Delta \mathrm{ROE}$ \\
\hline \multicolumn{7}{|c|}{ Agriculture } \\
\hline LSIP & 1.37 & 1.295 & $-6 \%$ & 0.3 & $-24 \%$ & $-18 \%$ \\
\hline \multicolumn{7}{|c|}{ Basic Industry } \\
\hline INTP & 19.4 & 16.55 & $-17 \%$ & 0.2 & $-14 \%$ & $-22 \%$ \\
\hline WTON & 434 & 395 & $-10 \%$ & 1.8 & $18 \%$ & $-2 \%$ \\
\hline \multicolumn{7}{|c|}{ Consumer Goods } \\
\hline GGRM & 54.6 & 54.2 & $-0.8 \%$ & 0.6 & $11 \%$ & $2 \%$ \\
\hline MLBI & 16 & 8.8 & $-82 \%$ & 2.1 & $20 \%$ & $2 \%$ \\
\hline SIDO & 1.27 & 885 & $-43 \%$ & 0.1 & $4 \%$ & $1 \%$ \\
\hline \multicolumn{7}{|c|}{ Finance } \\
\hline $\mathrm{ABDA}$ & 6.975 & 6.31 & $-11 \%$ & 1 & $6 \%$ & $-11 \%$ \\
\hline ADMF & 10.4 & 10 & $-4 \%$ & 3.8 & $18 \%$ & $4 \%$ \\
\hline ASBI & 276 & 266 & $-4 \%$ & 1.9 & $12 \%$ & $10 \%$ \\
\hline$\overline{\mathrm{BBCA}}$ & 31.4 & 27.2 & $-16 \%$ & 4.5 & $9 \%$ & $94 \%$ \\
\hline BBMD & 2.39 & 1.46 & $-64 \%$ & 2.6 & $5 \%$ & $-21 \%$ \\
\hline BBRI & 4.09 & 4.025 & $-2 \%$ & 5.9 & $-4 \%$ & $-6 \%$ \\
\hline MEGA & 6 & 5.45 & $-10 \%$ & 5 & $23 \%$ & $120 \%$ \\
\hline \multicolumn{7}{|c|}{ Infrastructure } \\
\hline TLKM & 3.93 & 3.83 & $-3 \%$ & 0.9 & $9 \%$ & $-17 \%$ \\
\hline \multicolumn{7}{|c|}{ Mining } \\
\hline MYOH & 1.265 & 1.135 & $-11 \%$ & 0.4 & $94 \%$ & $12 \%$ \\
\hline \multicolumn{7}{|c|}{ Miscellaneous Industry } \\
\hline TRIS & 268 & 230 & $-16 \%$ & 0.7 & $23 \%$ & $-12 \%$ \\
\hline \multicolumn{7}{|c|}{ Trade } \\
\hline GEMA & 366 & 335 & $-10 \%$ & 1.1 & $-3 \%$ & $-12 \%$ \\
\hline MNCN & 1.25 & 770 & $-62 \%$ & 0.5 & $19 \%$ & $-10 \%$ \\
\hline
\end{tabular}

\section{CONCLUSION}

Most successful investors perform stock purchasing transaction using the calculating basis of the intrinsic value of shares. The calculation of the intrinsic value of shares using the P / E method uses the company's fundamental data in the form of dividends, ROE, EPS, and DPR.

Based on the calculation results of intrinsic value, we classify into three types, namely (a) undervalue and feasible shares. There are five companies, namely ITMG, INKP, BSSR, TCID, and TURI, because the difference between intrinsic value and share price (MOS) is more than $30 \%$ and EPS and ROE growth is more than 9\%. DER is less than one, so the stock can be said to be able to survive in an intense competition situation and a slowdown in global economic growth. Besides that, the prospect of the industry is still quite good, although at this time, the capital market condition is still under pressure due to the Chinese and American trade war, so it is very suitable to buy shares at this time. (b) undervalue stocks that are not yet worth buying are 40 companies because financial performance in the form of EPS and ROE growth is relatively low, even harmful, and many of the DER ratios are above one, so the risk is relatively high. Moreover, (c) overvalued shares, there are 18 companies, and this stock is not worth buying because the intrinsic value is smaller than the stock price, so that if it is purchased, it can result in suffering losses due to the falling prices.

For further research on intrinsic value, we should compare using the Dividend Discounted Method (DDM) and 
Discounted Cash Flow (DCF) and with the same data so that at the time of performance evaluation, we can tell which method can produce a higher return.

\section{REFERENCES}

[1] E. May, Smart Traders Not Gamblers. Jakarta: Gramedia Pustaka Utama, 2017.

[2] R. Tiwari, "Intrinsic value estimates and its accuracy: Evidence from Indian manufacturing industry," Futur. Bus. J., vol. 2, no. 2, pp. 138151, 2016.

[3] R. Gottwald, "The Use of the P / E Ratio to Stock Valuation," Eur. Grant Proj. Results, Res. Dev. Sci., vol. 31, no. 2000, pp. 21-24, 2012.

[4] C. S. Mizrahi, Getting Started in Value Investing. Hoboken, New Jersey: John Wiley \& Sons, Inc., 2011.

[5] B. Graham, The Intelligent Investor: Ajaran-ajaran Inti Dalam

Berinvestasi. Pijar Nalar, 2016.

[6] A. M. Mehta, "Myth vs. Fact; Influence of Financial Leverage on Shareholder's Return (An Empirical Study of Sugar Sector of Pakistan from Year 2005-2010) Mr. Ahmed Muneeb Mehta 1," J. Financ. Bank Manag., vol. 2, no. 2, pp. 105-114, 2014.

[7] A. M. Bhatti, K. Majeed, Ijaz-ur-Rehman, and W. A. Khan, "Effect of leverage on risk and stock returns: Evidence from Pakistani companies," Int. Res. J. Financ. Econ., vol. 58, no. 58, pp. 32-49, 2010 .

[8] A. Halim, Analisis Investasi. Jakarta: Salemba Empat, 2013.

[9] J. Salim, 10 Investasi Paling Gampang \& Paling Aman. Visimedia, 2010.

[10] E. Tandelilin, Portofolio dan Investasi: Teori dan Aplikaksi. Yogyakarta: Penerbit Kanisius, 2010.

[11] S. Sunariyah, Pengantar Pengetahuan Pasar Modal, 5th ed. Bandung: CV Alfabeta, 2004

[12] E. T. Utami, Cara Cerdas Berinvestasi: via Online Trading, 1st ed. Jakarta: TransMedia, 2010.

[13] A. P. Tambunan, Menilai Harga Wajar Saham (Stock Valuation), 4th ed. Jakarta: Elex Media Komputindo, 2008.

[14] W. J. O’Neil, How to Make Money in Stocks: A Winning System in Good Times and Bad. MacGraw-Hill, 2009.

[15] E. S. Kayo, "EPS (earning per share) yang menyesatkan | Saham OK," Saham $O K$ [Online]. Available: https://www.sahamok.com/2012/04/28/eps-earning-per-share-yangmenyesatkan/. [Accessed: 16-Oct-2020].

[16] S. A. Ross, R. W. Westerfield, B. D. Jordan, J. Lim, and R. Tan, Fundamentals of Corporate Finance. McGraw Hill Education, 2016.

[17] L. F. Nurfadillah and N. F. Nuzula, "Analisis Dampak Ex-dividend date Pada Pembayaran Dividen Terhadap Abnormal Return (Studi Pada Perusahaan yang Terdaftar Dalam Indeks IDX High Dividend 20 Tahun 2018), “vol. 72, no. 1, pp. 91-99, 2019.

[18] D. Sjahrial, Manajemen Keuangan Lanjutan. Jakarta: Mitra Wacana Media, 2007.

[19] T. Darmadji and H. M. Fakhruddin, Pasar Modal di Indonesia: Pendekatan Tanya Jawab. Jakarta: Salemba Empat, 2001.

[20] M. Haritha, R. V Ravi V, and O. Ravisankar, "Intrinsic Value A Base to Pick Scrip," IOSR J. Bus. Manag., vol. 15, no. 3, pp. 01-05, 2013.

[21] M. Mayda, S. Batubara, S. Supriadi, F. Fenni, and R. Yulian, "The Strategy of Investment Decision Making Based on Fundamental Analysis," Int. J. Sci. Res. Publ., vol. 8, no. 12, pp. 401-409, 2018.

[22] S. Klarman, Risk-Averse Value Investing Strategies for the Thoughtful Investor. HarperBusiness, 2013. 